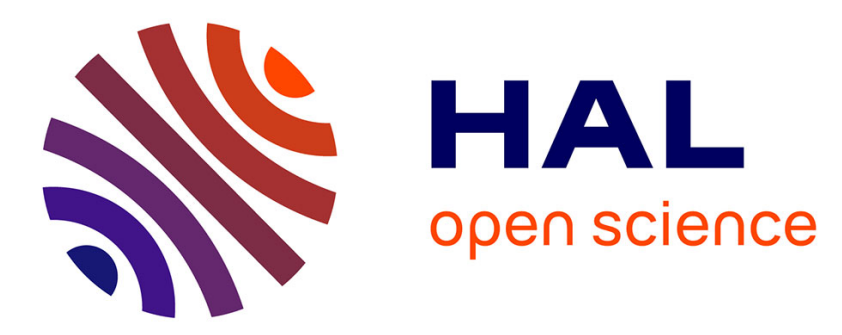

\title{
Maternal use of antihypertensive drugs in early pregnancy and delivery outcome, notably the presence of congenital heart defects in the infants
}

\author{
Roland Lennestål, Petra Otterblad Olausson, Bengt Källén
}

\section{To cite this version:}

Roland Lennestål, Petra Otterblad Olausson, Bengt Källén. Maternal use of antihypertensive drugs in early pregnancy and delivery outcome, notably the presence of congenital heart defects in the infants. European Journal of Clinical Pharmacology, 2009, 65 (6), pp.615-625. 10.1007/s00228-009-0620-0 . hal-00534944

\author{
HAL Id: hal-00534944 \\ https://hal.science/hal-00534944
}

Submitted on 11 Nov 2010

HAL is a multi-disciplinary open access archive for the deposit and dissemination of scientific research documents, whether they are published or not. The documents may come from teaching and research institutions in France or abroad, or from public or private research centers.
L'archive ouverte pluridisciplinaire HAL, est destinée au dépôt et à la diffusion de documents scientifiques de niveau recherche, publiés ou non, émanant des établissements d'enseignement et de recherche français ou étrangers, des laboratoires publics ou privés. 


\title{
Maternal use of antihypertensive drugs in early pregnancy and delivery outcome, notably the presence of congenital heart defects in the infants
}

\author{
Roland Lennestål • Petra Otterblad Olausson • \\ Bengt Källén
}

Received: 22 August 2008 / Accepted: 14 January 2009/Published online: 7 February 2009

(C) Springer-Verlag 2009

\begin{abstract}
Purpose To investigate the association between maternal use of antihypertensives in early pregnancy and delivery outcome, notably infant congenital malformations.

Methods A cohort study of 1,418 women who had used antihypertensive drugs in early pregnancy but had no diabetes diagnosis were identified from the Swedish Medical Birth Register.

Results There was an excess risk for placental abruption, caesarean section, delivery induction, and post-delivery hemorrhage in women taking hypertensives. Infants were more often than expected born preterm, were small for gestational age, and had an excess of various neonatal symptoms. Cardiovascular defects occurred with an adjusted odds ratio of 2.59 (95\% CI 1.92-3.51). The results were similar when the woman had used ACE inhibitors or other antihypertensives, notably beta blockers. Stillbirth rate was increased (risk ratio 1.87, 95\% CI 1.02-3.02), again without any clear drug specificity.

Conclusions There seems to be little drug specificity in the association between maternal use of antihypertensives and an increased risk for infant cardiovascular defects.
\end{abstract}

R. Lennestål

Department of Clinical Pharmacology, University of Umeå,

Umeå, Sweden

P. Otterblad Olausson

Centre for Epidemiology, National Board of Health and Welfare,

Stockholm, Sweden

B. Källén $(\bowtie)$

Tornblad Institute, University of Lund,

Biskopsgatan 7,

SE-223 62 Lund, Sweden

e-mail: Bengt.Kallen@med.lu.se
Keywords ACE inhibitors · Antihypertensives . Beta-blocking agents $\cdot$ Cardiovascular defects . Congenital malformations $\cdot$ Stillbirths

\section{Introduction}

Pregnancy in women with chronic hypertension has various severe complications including a worsening of the condition; an increased risk for preeclampsia, eclampsia and HELLP syndrome; liver or renal failure; placental abruption; miscarriage or fetal death; preterm birth and intrauterine growth restriction; and neonatal complications [1-4]. In order to reduce these risks, mild or moderate hypertension is usually carefully supervised and treated during pregnancy. According to a recent Cochrane review of the substantial relevant literature [5], the risk of severe hypertension can be reduced this way, but little effect is seen on maternal and neonatal complications.

Whether maternal hypertension in early pregnancy can increase the risk for a congenital malformation in the infant has been less extensively studied. In the classic Perinatal Project Study [6], there were only 53 women who had been treated in early pregnancy with antihypertensive agents (mainly rauwolfia alkaloids), and 5 of these women had malformed infants, whereas 280 women had used diuretics in early pregnancy and among these women, 15 had malformed infants. No statistically significant risk increase was found either for any malformations or for any specific malformation type.

In a study of maternal drug use and infant cardiovascular defects [7], an association was found with maternal use of antihypertensive drugs and beta-blocking agents in particular, but there was no statistically significant difference between different types of antihypertensive agents. The adjusted odds ratio for any antihypertensive was 2.0 and was slightly lower 
for beta-blocking agents (1.85). The association was investigated in a study based on a Medicaid database [8], which found that maternal use of ACE-inhibiting drugs was associated with an increased risk of infant congenital cardiovascular defects [risk ratio (RR) 3.72), while exposure to other antihypertensives had no such effect (RR0.89). The study was based on 209 exposures to ACE inhibitors, 202 to other hypertensives, and a comparison group of 29,096 infants without antihypertensive exposure.

In order to further evaluate the association between ACE inhibitors or other antihypertensive agents and infant congenital malformations, the present study was conducted using data in the Swedish Medical Birth Register.

\section{Material and methods}

The study was based on data in the Swedish Medical Birth Register [9]. This register contains medical information on nearly all infants born in Sweden since 1973, and since 1982 has been based on copies of medical documents from antenatal care, delivery care, and the pediatric examination of the newborns. Table 1 summarizes items in the register that have been used in the present analysis. Congenital malformations in infants were identified with the use of three nationwide registers: the Medical Birth Register, the Congenital Malformation Register, and the Hospital Discharge Register (up to 2006) [11].

Table 1 Data used from the registers

\begin{tabular}{|c|c|c|}
\hline Variable & Definition/source & Groups \\
\hline \multicolumn{3}{|l|}{ Maternal data } \\
\hline Year of delivery & & Single years: $1995-2006$ \\
\hline Maternal age & Completed years at delivery & 5 -year groups: $<20,20-24$, etc. \\
\hline Parity & Parity $1=$ no previous child & $1,2,3, \geq 4$ \\
\hline $\begin{array}{l}\text { Maternal smoking } \\
\text { in early pregnancy }\end{array}$ & Midwife interview & Unknown, $0,<10, \geq 10$ cigarettes per day \\
\hline Previous miscarriages & Midwife interview & $0,1,2, \geq 3$ \\
\hline Subfertility & $\begin{array}{l}\text { Number of years of unwanted childlessness, } \\
\text { midwife interview }\end{array}$ & $0,1,2,3,4, \geq 5$ \\
\hline Maternal BMI & $\begin{array}{l}\text { From pre-pregnancy weight and height at } \\
\text { first antenatal care visit }\end{array}$ & Unknown, $<19.8,19.8-25.9, \geq 26$ \\
\hline Maternal cohabitation & From midwife interview & Unknown, cohabiting, living alone, other \\
\hline Work outside home & From midwife interview & Unknown, full, part, none \\
\hline Maternal country of birth & Linked from Statistics Sweden & $\begin{array}{l}\text { Unknown, Sweden, other Nordic country, } \\
\text { other country }\end{array}$ \\
\hline Maternal education & $\begin{array}{l}\text { Only up to and including 2001, linked from } \\
\text { education register at Statistics Sweden }\end{array}$ & $\begin{array}{l}\text { Unknown, compulsory school or less, } \\
\text { gymnasium }{ }^{\mathrm{a}}, 2 \text { years post-gymnasium, } \\
\text { and } \geq 3 \text { years post-gymnasium }\end{array}$ \\
\hline \multicolumn{3}{|l|}{ Delivery and infant outcomes } \\
\hline Delivery diagnoses & From delivery record, based on ICD codes & $\begin{array}{l}\text { Preexisting and gestational diabetes, } \\
\text { placental abruption, antepartum and } \\
\text { postpartum bleeding }\end{array}$ \\
\hline Delivery method & From delivery record & Caesarean section, delivery induction \\
\hline Infant sex & From delivery record & Unknown, male, female \\
\hline Number of infants in birth & From delivery record & Singleton, twin, higher order \\
\hline Gestational duration & In most cases from second-trimester ultrasound & Preterm: $<37$ completed weeks (only singletons) \\
\hline Birth weight & From pediatric record & $\begin{array}{l}\text { Low birth weight: }<2,500 \mathrm{~g} \text {, high birth } \\
\text { weight: } \geq 4,500 \mathrm{~g} \text { (only singletons) }\end{array}$ \\
\hline Intrauterine growth & Defined from normal graphs [10] & SGA: $<-2$ SD, LGA: $>2$ SD \\
\hline Infant survival & From delivery record and linkage with Statistics Sweden & $\begin{array}{l}\text { Stillbirths }>28 \text { gestational weeks and live } \\
\text { births who died within } 1 \text { year }\end{array}$ \\
\hline Congenital malformations & $\begin{array}{l}\text { Ascertained from multiple sources [11]: the Medical } \\
\text { Birth Register, the Congenital Malformation Register, } \\
\text { and the Hospital Discharge Register up to } 2006\end{array}$ & $\begin{array}{l}\text { All infants with malformation diagnosis; infants } \\
\text { with relatively severe malformation; specific } \\
\text { groups of malformations }\end{array}$ \\
\hline Infant neonatal diagnoses & $\begin{array}{l}\text { From pediatric record. Conditions defined by ICD codes } \\
\text { and 5-min Apgar score }\end{array}$ & $\begin{array}{l}\text { Low Apgar score }(<7) \text {, diagnoses of respiratory } \\
\text { problems, hypoglycemia, neonatal icterus }\end{array}$ \\
\hline
\end{tabular}

$B M I$ Body mass index, $S G A$ small for gestational age, $L G A$ large for gestational age

"Swedish "gymnasium" is approximately equivalent to upper secondary high school in the U.K. and senior high school in the U.S. 
Beginning in 1994, maternal use of drugs during pregnancy has been registered [12]. This information is based on the midwife interview at the first antenatal visit ( $90 \%$ of women attend before week 12) and therefore mainly refers to first trimester exposure. Information on drugs prescribed for antenatal care during the whole pregnancy [12] is also available. All types of drugs are recorded, including prescription, over-the-counter, herbal, and homeopathic drugs. When possible, drug names were translated to ATC (Anatomical, Therapeutic, Chemical classification) codes.

In order to select women who reported use of antihypertensive drugs in early pregnancy, the following criteria were used: women who reported use of drugs for hypertension that have a sympaticolytic effect or that act on the smooth muscles of the arterioles, calcium-channel blockers, ACE inhibitors or angiotensin II blockers, irrespective of the presence of a delivery diagnosis code of chronic hypertension, and women who reported the use of a beta-blocking drug and had a delivery diagnosis of chronic hypertension. The reason for the latter restriction was that these drugs are widely used for other conditions, e.g., cardiac arrhythmia and as a prophylactic against migraine. Among all women who reported the use of betablocking drugs, $45 \%$ had no such diagnosis, but a proportion of them may well have had hypertension without having a delivery diagnosis.

We identified 1,618 women who reported the use of antihypertensives in early pregnancy and gave birth between July 1, 1995, and the end of 2006. Among them, $196(12.1 \%)$ had a diagnosis of pre-existing or gestational diabetes. In the population, there were 1,061,620 women who gave birth during this period, and 14,777 of them had a diagnosis of diabetes (1.4\%). Because of the strong association between diabetes and hypertension, women with a diagnosis of diabetes and also four women with unknown age in the register were removed from the analysis, which was therefore based on 1,418 women with 1,444 infants. Similar exclusions were made among the reference population.

\section{Statistical analysis}

Most of the analysis was made using the Mantel-Haenszel procedure with risk estimates from odds ratios (OR) after adjustment for putative confounders and with 95\% confidence intervals $(95 \% \mathrm{CI})$ determined with Miettinen's method. When the expected number of events was low $(<10)$, risk ratios $(\mathrm{RR})$ were instead used as the ratios between the observed numbers and the expected numbers, estimated after adjustments as above and with $95 \%$ CI from exact Poisson distributions (SABER software).

\section{Results}

Characteristics of women reporting the use of antihypertensive drugs

Tables 2 and 3 summarize the antihypertensive drugs used in early pregnancy among the studied women and describe the combinations of different antihypertensive drug groups. From the latter table, it can be seen that $84 \%$ of the women used drugs from only one category $(65 \%$ of them used beta blockers), $14 \%$ used drugs from two, and 1.3\% used drugs from three or four different groups of antihypertensives. Multiple antihypertensive drug treatment probably indicates a more severe hypertensive disease.

Tables 4 and 5 compare characteristics of women who reported the use of antihypertensive drugs with all women giving birth $(n=1,046,843)$. Drug use increased with maternal age and was higher at parity 1 than at higher parities. The women taking hypertensives smoked more in early pregnancy than other pregnant women, had more often had previous miscarriages, had a high BMI more often, and showed signs of subfertility in terms of increased periods of unwanted childlessness compared with other women. Antihypertensive use was less common among women born outside the Nordic countries than among Nordic-born women. The use of such drugs was lower in women with high than with low education. Women using such drugs were less often working full time outside the home than other women. Some of these characteristics may act as confounders in the analysis of pregnancy outcome.

Table 6 shows the use of other drugs among women who used antihypertensive drugs compared with all pregnant women. As would be expected, there was a markedly higher number of diuretics and serum lipidlowering drugs (even though only a few women used the latter). There was also a greater use of some other drugs that may indicate co-morbidity: drugs used for stomach ulcers, systemic corticosteroids, thyroid drugs, drugs for migraine, and antidepressants. Use of each one of these drug categories occurred, however, in less than $5 \%$ of all women taking antihypertensives.

Among delivery diagnoses, an excess of placental abruption was found. Of the 1,418 women using antihypertensives, 15 had a placental abruption and the expected number (adjusted for year of birth, maternal age, parity, smoking, and BMI) was 6.7 (RR2.25, 95\% CI 1.26-3.70). Caesarean sections also occurred in excess; $33 \%$ of all deliveries occurred after caesarean section among women who had used antihypertensive drugs compared with $15 \%$ in the population. The adjusted OR was $2.12(95 \% \mathrm{CI}$ 1.89-2.37). The excess of caesarean sections remained when the analysis was restricted to term infants: $26 \%$ after 
Table 2 Antihypertensive drugs used by women in early pregnancy

\begin{tabular}{|c|c|}
\hline Drug & Number \\
\hline \multicolumn{2}{|c|}{ Antiadrenergic agents, centrally acting } \\
\hline Methyldopa & 36 \\
\hline Clonidine & 6 \\
\hline \multicolumn{2}{|c|}{ Antiadrenergic agents, peripherally acting } \\
\hline Doxazosin & 7 \\
\hline Terazosin & 1 \\
\hline \multicolumn{2}{|c|}{ Agents acting on arteriolar smooth muscles } \\
\hline Diazoxide & 2 \\
\hline Hydralazine & 58 \\
\hline \multicolumn{2}{|l|}{ Beta-blocking agents } \\
\hline Pindolol & 129 \\
\hline Propanolol & 26 \\
\hline Sotalol & 1 \\
\hline Metoprolol & 349 \\
\hline Atenolol & 303 \\
\hline Betaxolol & 3 \\
\hline Bisoprolol & 9 \\
\hline Labetalol & 184 \\
\hline Carvedilol & 9 \\
\hline \multicolumn{2}{|c|}{ Calcium-channel blockers } \\
\hline Amlodipine & 47 \\
\hline Felodipine & 108 \\
\hline Isradipine & 55 \\
\hline Nicardipine & 2 \\
\hline Nifedipine & 53 \\
\hline Verapamil & 75 \\
\hline Diltiazem & 3 \\
\hline \multicolumn{2}{|c|}{ ACE inhibitors (with combinations) } \\
\hline Captopril & 5 \\
\hline Enalapril & 106 \\
\hline Lisinopril & 14 \\
\hline Lisinopril + diuretic & 2 \\
\hline Ramipril & 11 \\
\hline Ramipril + diuretic & 3 \\
\hline Quinapril & 3 \\
\hline Quinapril + diuretic & 2 \\
\hline Cilazapril & 7 \\
\hline Cilazapril + diuretic & 3 \\
\hline Fosinopril & 1 \\
\hline \multicolumn{2}{|c|}{ Angiotensin II antagonists (with diuretic combinations) } \\
\hline Losartan & 28 \\
\hline Losartan + diuretic & 4 \\
\hline Valsartan & 8 \\
\hline Irbesartan & 7 \\
\hline Irbesartan + diuretic & 2 \\
\hline Candesartan & 26 \\
\hline Telmisartan & 2 \\
\hline
\end{tabular}

As some women used more than one drug, the total number of drugs used will exceed the number of women

the use of antihypertensives compared with $14 \%$ in the population (OR 1.61, 95\% CI 1.41-1.84).

Among 1,146 deliveries by women taking antihypertensives that did not start with a caesarean section, $454(40 \%)$ had a delivery induction compared with $11 \%$ in the population. The adjusted odds ratio was 4.35 (95\% CI 3.88-4.88). There was no increase in risk for antepartum bleeding ( 7 cases observed compared with 8.5 expected), but there was an excess of postpartum bleeding $(n=108$, OR $1.46,95 \%$ CI 1.19-1.79).

Characteristics of infants born to women who reported the use of antihypertensive drugs in early pregnancy

Table 7 shows some characteristics of infants born to women who used antihypertensives in early pregnancy and had no diabetes diagnosis. The multiple birth rate was normal. Among singleton infants, the risk for preterm birth, low birth weight, and being small for gestational age was markedly increased, while the risk for heavy infants or

Table 3 Combinations of antihypertensive drug groups reported in early pregnancy

\begin{tabular}{ll}
\hline Drug groups & Number \\
\hline One drug group only & 1,196 \\
Beta-blocking agents & 778 \\
Calcium-channel blockers & 210 \\
ACE inhibitors & 105 \\
Angiotensin II antagonists & 46 \\
Other & 57 \\
Combinations of two drug groups & 203 \\
Beta-blocking agents + calcium-channel blockers & $107^{\mathrm{a}}$ \\
Beta-blocking agents + ACE inhibitors & 231 \\
Beta-blocking agents + angiotensin II antagonists & 221 \\
Beta-blocking agents + other & 34 \\
Calcium-channel blockers + ACE inhibitors & 4 \\
Calcium-channel blockers + angiotensin II antagonists & 0 \\
Calcium-channel blockers + other & 4 \\
ACE inhibitors + angiotensin II antagonists & 2 \\
ACE inhibitors + other & 5 \\
Angiotensin II antagonists + other & 2 \\
Combinations of three or four drug groups & 19 \\
Beta-blocking agent + ACE inhibitor + & 3 \\
angiotensin II antagonist & \\
Beta-blocking agent + calcium-channel blocker + & 10 \\
ACE inhibitor & 1 \\
Beta-blocking agent + calcium-channel blocker + other & 1 \\
Beta-blocking agent + ACE inhibitor + other & 1 \\
Beta-blocking agent + calcium-channel blocker + & 2 \\
ACE inhibitor + other & \\
Beta-blocking agent + calcium-channel blocker + & \\
angiotensin II antagonist + other & \\
Calcium-channel blocker + ACE inhibitor + & \\
angiotensin II antagonist & \\
& \\
\hline
\end{tabular}

Other refers to antiadrenergic agents and agents acting on arteriolar smooth muscles

${ }^{\mathrm{a}}$ In nine cases, this was a fixed drug combination (Logimax: felodipine and metoprolol) 
Table 4 Characteristics among women who reported the use of antihypertensive drugs in early pregnancy

\begin{tabular}{|c|c|c|c|c|}
\hline $\begin{array}{l}\text { Variable } \\
\text { studied }\end{array}$ & $\begin{array}{l}\text { Using } \\
\text { antihypertensives }\end{array}$ & Total & OR & $95 \% \mathrm{CI}$ \\
\hline All women & 1,418 & $1,046,843$ & - & - \\
\hline \multicolumn{5}{|l|}{ Maternal age } \\
\hline$<20$ & 7 & 19,672 & 0.30 & $0.15-0.62$ \\
\hline $20-24$ & 56 & 146,612 & 0.28 & $0.21-0.36$ \\
\hline $25-29$ & 254 & 344,481 & 0.49 & $0.42-0.56$ \\
\hline $30-34$ & 495 & 354,948 & 1.01 & $0.90-1.13$ \\
\hline $35-39$ & 436 & 152,804 & 2.20 & $1.97-2.46$ \\
\hline $40-44$ & 166 & 27,267 & 3.84 & $3.28-4.51$ \\
\hline$\geq 45$ & 4 & 1,059 & 1.84 & - \\
\hline$<25$ & 63 & 166,284 & 0.36 & $0.28-0.46$ \\
\hline $25-34$ & 749 & 699,429 & 1.00 & Reference \\
\hline$\geq 35$ & 606 & 181,130 & 2.89 & $2.59-3.22$ \\
\hline \multicolumn{5}{|l|}{ Parity } \\
\hline 1 & 531 & 458,641 & 1.25 & $1.12-1.40$ \\
\hline 2 & 479 & 378,518 & 0.90 & $0.81-1.01$ \\
\hline 3 & 241 & 144,976 & 0.89 & $0.77-1.02$ \\
\hline$\geq 4$ & 167 & 64,708 & 0.94 & $0.79-1.11$ \\
\hline \multicolumn{5}{|c|}{ Smoking in early pregnancy } \\
\hline Unknown & 51 & 75,714 & - & - \\
\hline None & 1,200 & 859,134 & 1.00 & Reference \\
\hline$<10$ cigarettes/day & 101 & 77,197 & 1.06 & $0.86-1.21$ \\
\hline$\geq 10$ cigarettes/day & 66 & 34,798 & 1.33 & $1.03-1.72$ \\
\hline Any smoking & 167 & 111,995 & 1.25 & $0.99-1.58$ \\
\hline \multicolumn{5}{|c|}{ Number of previous miscarriages } \\
\hline 0 & 1,011 & 844,261 & 1.00 & Reference \\
\hline 1 & 320 & 155,819 & 1.31 & $1.15-1.49$ \\
\hline 2 & 55 & 33,882 & 0.86 & $0.65-1.14$ \\
\hline$\geq 3$ & 32 & 12,881 & 1.11 & $0.77-1-60$ \\
\hline Any miscarriage & 407 & 202582 & 1.16 & $1.03-1.31$ \\
\hline \multicolumn{5}{|c|}{ Maternal body mass index } \\
\hline Unknown & 161 & 157,074 & - & - \\
\hline$<19.8$ & 63 & 78,847 & 0.93 & $0.72-1.21$ \\
\hline $19.8-25.9$ & 578 & 575,619 & 1.00 & Reference \\
\hline$\geq 26$ & 616 & 235,303 & 2.44 & $2.18-2.72$ \\
\hline
\end{tabular}

Odds ratios (OR) were adjusted for year of delivery and all other variables in the table, and $95 \%$ confidence intervals $(95 \% \mathrm{CI})$ were estimated. For maternal age and parity, each group was compared with all other groups

being large for gestational age was significantly decreased. All neonatal diagnoses listed in Table 7 occurred at significantly increased rates. All ORs decreased when the study was restricted to term infants but remained significant with the exception of the OR for respiratory diagnoses. The latter effect seemed to be exclusively due to preterm births. The effect on respiratory diagnoses in infants exposed to beta blockers was slightly stronger than with other antihypertensive drugs (OR 1.96, 95\% CI 1.58-2.43), but the difference was not statistically significant. Among term infants, the OR was not significantly increased (OR 1.23, 95\% CI 0.87-1.93).
The risk of a congenital malformation was significantly increased among infants whose mothers used antihypertensives in early pregnancy, and the OR estimate even increased slightly when some common mild and variably registered malformations were excluded. There was a marked effect on the risk for a cardiac defect, which was especially clear for ventricular or atrium septum defects (in the absence of other cardiovascular defects). Among infants without a cardiac defect, the risk of a congenital malformation was not significantly increased. The only such specific condition that showed an increase that was

Table 5 Some further characteristics among women who reported the use of antihypertensive drugs in early pregnancy

\begin{tabular}{|c|c|c|c|c|}
\hline $\begin{array}{l}\text { Variable } \\
\text { studied }\end{array}$ & $\begin{array}{l}\text { Using } \\
\text { antihypertensives }\end{array}$ & Total & OR & $95 \% \mathrm{CI}$ \\
\hline \multicolumn{5}{|c|}{ Years of unwanted childlessness } \\
\hline 0 & 1,249 & 975,375 & 1.00 & Reference \\
\hline 1 & 33 & 19,792 & 1.06 & $0.75-1.50$ \\
\hline 2 & 48 & 20,979 & 1.33 & $1.00-1.78$ \\
\hline 3 & 20 & 11,503 & 0.94 & $0.60-1.46$ \\
\hline 4 & 21 & 6,608 & 1.54 & $1.00-2.39$ \\
\hline$\geq 5$ & 47 & 12,586 & 1.69 & $1.25-2.29$ \\
\hline $\begin{array}{l}\text { Any unwanted } \\
\text { childlessness }\end{array}$ & 169 & 71,468 & 1.30 & $1.10-1.54$ \\
\hline \multicolumn{5}{|l|}{ Maternal country of birth } \\
\hline Unknown & 12 & 10,304 & - & - \\
\hline Sweden & 1,236 & 852,407 & 1.00 & Reference \\
\hline Other Nordic country & 55 & 24,274 & 1.25 & $0.95-1.65$ \\
\hline Non-Nordic country & 115 & 159,858 & 0.50 & $0.41-0.60$ \\
\hline \multicolumn{5}{|c|}{ Maternal education (up to and including 2001) } \\
\hline Unknown & 14 & 18,428 & - & - \\
\hline $\begin{array}{l}\text { Compulsory school } \\
\text { or less }\end{array}$ & 81 & 65,610 & 0.88 & $0.67-1.17$ \\
\hline Gymnasium $^{\mathrm{a}}$ & 323 & 290,448 & 1.00 & Reference \\
\hline $\begin{array}{l}2 \text { years post- } \\
\text { gymnasium }\end{array}$ & 27 & 31,068 & 0.69 & $0.46-1.01$ \\
\hline $\begin{array}{c}3 \text { or more years } \\
\text { post-gymnasium }\end{array}$ & 179 & 160,436 & 0.77 & $0.64-0.93$ \\
\hline \multicolumn{5}{|l|}{ Maternal family situation } \\
\hline Unknown & 25 & 68,514 & - & - \\
\hline Co-habiting & 1320 & 927,271 & 1.00 & Reference \\
\hline Living alone & 47 & 26,295 & 1.25 & $0.93-1.68$ \\
\hline Other & 26 & 24,763 & 0.70 & $0.47-1.05$ \\
\hline \multicolumn{5}{|l|}{ Maternal work situation } \\
\hline Unknown & 164 & 189,875 & - & - \\
\hline Full-time work & 625 & 458,415 & 1.00 & Reference \\
\hline Part-time work & 367 & 231,122 & 1.23 & $1.08-1.41$ \\
\hline $\begin{array}{l}\text { No work outside } \\
\text { home }\end{array}$ & 262 & 167,431 & 1.29 & $1.11-1.50$ \\
\hline
\end{tabular}

${ }^{\text {a }}$ Swedish gymnasium is approximately equivalent to upper secondary school in the U.K. and senior high school in the U.S.

Odds ratios (OR) were adjusted for year of delivery, maternal age, parity, and smoking, and $95 \%$ confidence intervals $(95 \% \mathrm{CI})$ were estimated. 
Table 6 Concomitant drug use in women who reported the use of antihypertensive drugs in early pregnancy

\begin{tabular}{|c|c|c|c|c|}
\hline Drug category & $\begin{array}{l}\text { Using } \\
\text { antihypertensives }\end{array}$ & Total & OR & $95 \% \mathrm{CI}$ \\
\hline $\begin{array}{l}\text { Drugs for stomach } \\
\text { ulcers }\end{array}$ & 31 & 8,025 & 2.09 & $1.47-2.97$ \\
\hline Multivitamins & 56 & 34,397 & 0.93 & $0.71-1.22$ \\
\hline Folic acid & 67 & 35,060 & 1.05 & $0.82-1.35$ \\
\hline Diuretics & 118 & 465 & 170 & $147-197$ \\
\hline $\begin{array}{l}\text { Serum lipid-lowering } \\
\text { drugs }\end{array}$ & 10 & 176 & $15.4^{\mathrm{a}}$ & $7.38-28.3$ \\
\hline $\begin{array}{l}\text { Systemic } \\
\text { corticosteroids }\end{array}$ & 35 & 3,710 & $5.51^{\mathrm{a}}$ & $3.84-7.67$ \\
\hline Thyroid drugs & 58 & 11,880 & 2.35 & $1.81-3.05$ \\
\hline Antibiotics & 29 & 30,261 & 0.68 & $0.47-0.95$ \\
\hline NSAID & 33 & 18,247 & 1.11 & $0.79-1.56$ \\
\hline Opioids & 14 & 4,995 & 1.41 & $0.83-2.40$ \\
\hline Minor analgesics & 99 & 78,980 & 0.79 & $0.64-0.97$ \\
\hline $\begin{array}{l}\text { Drugs against } \\
\text { migraine }\end{array}$ & 13 & 2,888 & $2.55^{\mathrm{a}}$ & $1.36-4.36$ \\
\hline Anticonvulsants & 6 & 2,718 & $1.44^{\mathrm{a}}$ & $0.53-3.13$ \\
\hline $\begin{array}{l}\text { Sedatives and } \\
\text { hypnotics }\end{array}$ & 6 & 4,434 & $0.63^{\mathrm{a}}$ & $0.23-1.38$ \\
\hline Antidepressants & 53 & 13,476 & 2.20 & $1.68-2.90$ \\
\hline Antiasthmatics & 71 & 31,016 & 1.49 & $1.17-1.90$ \\
\hline Antihistamines & 72 & 57,625 & 0.90 & $0.71-1.14$ \\
\hline For NVP & 47 & 44,467 & 0.79 & $0.59-1.06$ \\
\hline For allergy & 26 & 18,412 & 0.92 & $0.62-1.36$ \\
\hline
\end{tabular}

NSAID Nonsteroidal anti-inflammatory drug, NVP nausea and vomiting in pregnancy

Odds ratios (OR) and risk ratios (RR) are adjusted for year of delivery, maternal age, parity, smoking, and BMI, and $95 \%$ confidence intervals $(95 \% \mathrm{CI})$ were estimated. Women with a diagnosis of diabetes were excluded

${ }^{a}$ Risk ratios (RR) calculated as observed over expected numbers with exact $95 \%$ CI based on Poisson distributions

formally statistically significant was pes equinovarus, based on seven cases, of which one had only pes equinovarus and the other were combined with and sometimes secondary to other malformations (e.g., spina bifida, hydrocephaly).

Table 8 presents analyses of the association between specific antihypertensive drugs and cardiovascular defects. The risk estimate when the woman used only one type of antihypertensive drug was lower than when she used two or more, but the difference may be random. If she used an ACE inhibitor, the risk was slightly higher than if she did not, but again this difference could be random, and the effect of the ACE inhibitor was not by itself statistically significant. When the mother had only used beta-receptor blockers, the risk estimate was high and statistically significant.

Since the use of antihypertensive drugs was associated with the use of some other drugs, the analysis was repeated after exclusion of women who had also used diuretics, serum lipid-lowering drugs, drugs for stomach ulcer, systemic corticosteroids, thyroid drugs, drugs for migraine, or antidepressants. None of these drugs has a marked teratogenic effect, and the resulting OR for relatively severe malformations did not change (OR 1.63, 95\% CI 1.26-2.12).

Table 9 lists the congenital malformations observed and the antihypertensive drug groups used by the mothers of the malformed infants. There were 5 infants with CNS malformations (2.3 expected); none of these mothers had used ACE inhibitors.

The total number of infants that were stillborn $(\geq 28$ weeks gestational duration) or died during the first year of life was 19 out of $1,444(1.3 \%)$. In the total population, 5,746 died among $1,063,081$ born $(0.5 \%)$, and the adjusted RR for death was 1.87 (95\% CI 1.02-3.02). Among the dead infants, 14 were stillborn, 2 died during the first week of life, 2 at the age of 11 days, and 1 at the age of 95 days. Table 10 provides information on drugs used in early pregnancy and in late pregnancy (when known) and causes of death for infants born alive. In three of the cases, an ACE inhibitor was used in early pregnancy, and one of these mothers was prescribed such a drug later in pregnancy as well. Two women with stillbirths had used angiotensin II antagonists; one did not continue with the drug, and in the second case, drug use in late pregnancy was unknown.

\section{Discussion}

The women studied were selected based on their reported use of antihypertensive drugs in early pregnancy as recorded at the first antenatal care visit. All women reporting such drugs may not have had chronic hypertension. Some of them had received a diagnosis of pre-existing hypertension at delivery, but such diagnoses were certainly not always given. This is of special relevance for betablocking drugs, which are often used for other medical conditions than hypertension in this particular age group. If a woman had used a beta blocker as the only antihypertensive, she was only included in the study if she also had a delivery diagnosis of pre-existing hypertension. Thus, some women with hypertension were excluded from the study, namely, if they had only used a beta blocker and had no diagnosis indicating hypertension at delivery. Some of the other antihypertensive drugs are also used in patients without hypertension and notably at cardiac failure, but such cases should be very rare among pregnant women.

There was a relatively high proportion of pre-existing or gestational diabetes among the women who were primarily selected for study. As both of these conditions have a marked effect on pregnancy outcome including the presence of congenital malformations in the infant (notably preexisting diabetes), such women were excluded from further 
Table 7 Some characteristics of infants born to women who reported the use of antihypertensives in early pregnancy

\begin{tabular}{|c|c|c|c|c|}
\hline Variable studied & With drug & Total & $\mathrm{OR} / \mathrm{RR}^{\mathrm{a}}$ & $95 \% \mathrm{CI}$ \\
\hline \multicolumn{5}{|l|}{ Number of infants in birth } \\
\hline Singletons & 1,391 & $1,030,703$ & 1.00 & Reference \\
\hline Twins & 26 & 15,907 & 1.04 & $0.70-1.53$ \\
\hline Triplets/quadriplets & 1 & 233 & - & - \\
\hline \multicolumn{5}{|l|}{ Among singleton births } \\
\hline Preterm birth $(<37$ weeks $)$ & 214 & 51,087 & 3.33 & $2.89-3.84$ \\
\hline Low birth weight $(<2,500 \mathrm{~g})$ & 199 & 35,315 & 4.72 & $4.11-5.41$ \\
\hline High birth weight $(\geq 4,500 \mathrm{~g})$ & 24 & 41,158 & 0.40 & $0.37-0.59$ \\
\hline Small for gestational age & 122 & 22,293 & 4.23 & $3.55-5.03$ \\
\hline Large for gestational age & 64 & 59,996 & 0.70 & $0.54-0.89$ \\
\hline \multicolumn{5}{|l|}{ Among all births } \\
\hline Hypoglycemia & 127 & 26,393 & 2.96 & $2.48-3.55$ \\
\hline Only term infants & 70 & 17,909 & 2.57 & $2.02-3.28$ \\
\hline Neonatal icterus & 155 & 42,780 & 2.62 & $2.22-3.09$ \\
\hline Only term infants & 47 & 19,401 & 1.87 & $1.39-2.51$ \\
\hline Low Apgar score ${ }^{b}$ & 34 & 15,644 & 1.50 & $1.06-2.12$ \\
\hline Only term infants & 21 & 10,586 & 1.47 & $0.95-2.26$ \\
\hline Respiratory diagnoses & 123 & 47,710 & 1.74 & $1.45-2.10$ \\
\hline Only term infants & 43 & 31,204 & 1.01 & $0.74-1.38$ \\
\hline Any malformation & 92 & 46,471 & 1.51 & $1.22-1.86$ \\
\hline Relatively severe malformation $^{\mathrm{c}}$ & 72 & 33,686 & 1.63 & $1.28-2.06$ \\
\hline \multicolumn{5}{|l|}{ Excluding chromosome anomalies } \\
\hline Any cardiovascular defect & 42 & 12,660 & 2.59 & $1.92-3.51$ \\
\hline VSD and/or ASD & 34 & 6,409 & $2.67^{\mathrm{a}}$ & $1.71-3.98$ \\
\hline Without cardiac defects & 30 & 20,413 & 1.14 & $0.80-1.62$ \\
\hline Any CNS malformation & 5 & 1,981 & $2.21^{\mathrm{a}}$ & $0.72-5.15$ \\
\hline Hypospadias & 6 & 3,588 & $1.31^{\mathrm{a}}$ & $0.48-2.85$ \\
\hline Pes equinovarus & 7 & 1,689 & $3.18^{\mathrm{a}}$ & $1.28-6.55$ \\
\hline Hip (sub)dislocation & 7 & 6,281 & $0.81^{\mathrm{a}}$ & $0.33-1.67$ \\
\hline
\end{tabular}

$A S D$ Atrium septum defect, VSD ventricular septum defect

Odds ratios (OR) or risk ratios (RR) were adjusted for year of delivery, maternal age, parity, smoking, and BMI, and 95\% confidence intervals $(95 \%$ CI) were estimated. There were 1,390 singletons exposed to antihypertensives with known pregnancy duration and 1,384 with known birth weight. In the population, the numbers were $1,029,635$ and 1,026,215, respectively

${ }^{a}$ Relative risk (RR) was calculated as the observed number of cases over the expected number and with 95\% CI estimated from exact Poisson distributions

${ }^{\mathrm{b}}$ Apgar score $<7$ at $5 \mathrm{~min}$

${ }^{\mathrm{c}}$ The following conditions were excluded: preauricular appendix, tongue tie, PDA at preterm birth, single umbilical artery, undescended testicle, nevus

analysis. Some diabetic women may not have been identified, notably women with gestational diabetes. The strongest effect on malformation rate emanates from preexisting diabetes, while the observed effects on malformation rates owing to gestational diabetes are much weaker and probably due to undetected diabetes type 2 in early pregnancy [13].

Women who were treated with antihypertensives in early pregnancy deviated in many ways from other women. Some of these factors could act as confounders, notably in the study of maternal and infant morbidity: high maternal age, first infant born, excess smoking, and high BMI. Some could contribute to confounding, but due to low numbers were not likely to be important, e.g., four to five years of subfertility. It seems likely that chronic hypertension increases the risk of miscarriage. Adjustment for the number of years of unwanted childlessness was made but did not influence risk estimates noticeably. Previous miscarriage appeared as a possible confounder, but this was linked only to one previous miscarriage, a phenomenon with little impact on delivery outcome. Women who were born outside the Nordic countries had a lower rate of antihypertensive drug use than women born in the Nordic countries. If anything, delivery outcome was worse in the former group than in the latter, but in Sweden the country of origin of the pregnant woman has relatively little effect on pregnancy outcome. Women with a high education had a lower use of antihypertensive drugs (also after adjustment 
Table 8 Risk for any cardiovascular defect according to antihypertensive drug(s) used in early pregnancy

\begin{tabular}{|c|c|c|c|c|}
\hline \multirow{2}{*}{$\begin{array}{l}\text { Antihypertensive } \\
\text { drugs used }\end{array}$} & \multicolumn{2}{|c|}{ Number of infants } & \multirow[t]{2}{*}{$\mathrm{OR} / \mathrm{RR}^{\mathrm{a}}$} & \multirow[t]{2}{*}{$95 \% \mathrm{CI}$} \\
\hline & Malformed & Total & & \\
\hline More than one drug group & 9 & 218 & $4.00^{\mathrm{a}}$ & $1.83-7.60$ \\
\hline Only one drug group & 33 & 1,226 & 2.37 & $1.68-3.35$ \\
\hline ACE inhibitor & 5 & 150 & $2.90^{\mathrm{a}}$ & $0.94-6.76$ \\
\hline Other than ACE inhibitor & 37 & 1,294 & 2.54 & $1.84-3.52$ \\
\hline Only beta-blocking agent & 25 & 798 & 2.76 & $1.79-4.08$ \\
\hline $\begin{array}{l}\text { Only calcium-channel } \\
\text { blocker }\end{array}$ & 3 & 217 & $1.15^{\mathrm{a}}$ & $0.24-3.35$ \\
\hline Only ACE inhibitor & 2 & 91 & $1.68^{\mathrm{a}}$ & $0.20-6.08$ \\
\hline $\begin{array}{l}\text { Only angiotensin II } \\
\text { antagonist }\end{array}$ & 0 & 45 & $0.00^{\mathrm{a}}$ & $0.00-8.25$ \\
\hline Only other & 3 & 67 & $2.50^{\mathrm{a}}$ & $0.52-7.32$ \\
\hline
\end{tabular}

Odds ratio (OR) after adjustment for year of bith, maternal age, parity, smoking, and BMI with $95 \%$ confidence interval $(95 \% \mathrm{CI})$

${ }^{a}$ Relative risk (RR) was calculated as the observed number of cases over the expected number and with 95\% CI estimated from exact Poisson distributions

for age, parity, and smoking), but education has little effect on pregnancy outcome in Sweden. Women taking antihypertensives more often than other women did not work outside the home, which may have been an effect of the disease.

A certain amount of co-morbidity (except from diabetes) could be demonstrated from the analysis of concomitant drug use. None of the associated diseases had a known strong teratogenic effect, and exclusion of all women using such drugs hardly affected the risk of a congenital malformation.

We could demonstrate that the women studied had an increased risk for placental abruption, preterm delivery, caesarean sections, and delivery inductions - all known consequences of chronic hypertension [1-4]. Effects on the infants such as low birth weight, being small for gestational age, and some neonatal diagnoses could also be verified. The increased risk for neonatal diagnoses was to some extent (notably for respiratory problems) associated with preterm birth.

There was an increased risk for infant mortality. An increased risk for stillbirth is well known when ACE inhibitors and angiotensin II antagonists are used, but few mothers of the dead infants had used these drugs early in pregnancy and only one later in pregnancy.

The central observation of this study relates to the risk of congenital malformations. As described in the "Introduction" section, it has been postulated that the use of ACE inhibitors but not other antihypertensives is associated with an increased risk of cardiovascular defects [8]. The present analysis verifies the observation of an increased risk for such malformations after treatment with ACE inhibitors, but a similar risk was found following the use of other antihypertensives, notably beta blockers. In our material, ACE inhibitors represented a much smaller proportion of the drugs used - among 1,418 women, only 137 had used ACE inhibitors, whereas in the U.S. study [8], more than half of the infants studied had been exposed to such drugs (207 infants). The risk estimates from the two studies were in the same order of magnitude, and in both, the dominant cardiovascular malformations were septal defects. The earlier results were questioned [14] from two points of view: the possible confounding effects of maternal diabetes and of high BMI. In this analysis, women with known diabetes (both pre-existing and gestational) were excluded, and adjustment for BMI was made.

The main difference between the two studies was that, in our study, we found a similar effect when the woman had used antihypertensives other than ACE inhibitors and notably if she had used beta blockers, while in the U.S. study, no effect was found when other antihypertensives were used. Our data set included 1,281 infants exposed to other antihypertensives than ACE inhibitors, while the U.S. study [8] contained 202 such infants. Among the latter, infants exposed to angiotensin II antagonists were excluded.

Our results suggest that the cardiovascular teratogenic effect is not a characteristic of ACE inhibitors, as claimed, but is also seen with other antihypertensives and notably beta blockers. There are various possible explanations for such an effect. One obvious possibility would be that the underlying disease, chronic hypertension, is the true risk factor [1]. Another possibility is that the antihypertensive drugs could cross the placenta and could disturb fetal circulation, leading to an increased risk for septal defects.

Data concerning human placental passage for antihypertensive drugs in general are incomplete [15]. However, most beta blockers are described to cross the placenta. Of the ACE inhibitors, at least enalapril is known to cross the human placenta. Captopril was found in cord blood in one case after caesarean section at 34 weeks. For trandolapril and lisinopril, there seems to be no data. Concerning calcium antagonists, it is described that verapamil, isradipine, and nimodipine pass the placenta at term, but no data were found concerning placental passage in early pregnancy. For amlodipine, no data were found. Placental passage of the angiotensin II receptor antagonists seems not to have been studied.

Hypotension induced by antihypertensive drugs could be a possible cause of malformations. Fetal deaths in rabbits and stillborn lambs, rather than malformations, have been described during antihypertensive treatment (ACE inhibitors) in connection with decreased perfusion of the placenta, systemic hypotension, and reduced fetal blood pressure [16]. 
Table 9 Congenital malformations identified among infants whose mothers used antihypertensive drugs in early pregnancy

\begin{tabular}{|c|c|c|c|c|}
\hline Congenital malformation & $\begin{array}{l}\text { Sympaticus } \\
\text { blocker }\end{array}$ & $\begin{array}{l}\text { Beta-blocking } \\
\text { agent }\end{array}$ & $\begin{array}{l}\text { Calcium-channel } \\
\text { blocker }\end{array}$ & $\begin{array}{l}\text { ACE } \\
\text { inhibitor }\end{array}$ \\
\hline \multicolumn{5}{|l|}{ Major malformations } \\
\hline Hydrocephaly & & 1 & & \\
\hline Hydrocephaly + VSD + ASD & & 1 & & \\
\hline Hydrocephaly + vesico-ureteral reflux & 1 & & & \\
\hline Spina bifida + VSD & & 1 & & \\
\hline Arnold-Chiari + unstable hip & & 1 & & \\
\hline Cataract + pes equinovarus & & 1 & & \\
\hline Cataract + unspecified syndrome & & 1 & & \\
\hline Glaucoma + vesicoureteral reflux & & 1 & & \\
\hline Common truncus & & & & 1 \\
\hline VSD & & 9 & $1^{\mathrm{a}}$ & 2 \\
\hline VSD + aortic stenosis & $1^{\mathrm{a}}$ & & & \\
\hline VSD + bladder diverticle + undescended testicle & $1^{\mathrm{a}}$ & & & \\
\hline $\mathrm{VSD}+\mathrm{ASD}$ & & & 2 & \\
\hline $\mathrm{VSD}+\mathrm{ASD}+$ coarctation of aorta & & 1 & & \\
\hline ASD & 1 & 3 & & \\
\hline ASD + branchial cyst & & 1 & & \\
\hline ASD + vesico-ureteral reflux & & & $1^{\mathrm{a}}$ & \\
\hline HLHS & & 1 & & \\
\hline HLHS + coarctation of aorta & & & $1^{\mathrm{a}}$ & \\
\hline HLHS + ear aplasia & & & & 1 \\
\hline Aortic stensois + peripheral vessel malformation & & 1 & & \\
\hline Aortic stenosis and insufficiency & & & & $1^{\mathrm{a}}$ \\
\hline Mitral insufficiency + undescended testicle & & & $1^{\mathrm{a}}$ & \\
\hline Coarctation of aorta + undescended testicle & & 1 & & \\
\hline Cleft lip + spine deformity & & 1 & & \\
\hline Cleft palate + ASD + hypospadias & & 1 & & \\
\hline Pylorostenosis & & 1 & & \\
\hline Small gut atresia + undescended testicle & & & 1 & \\
\hline Anal atresia + unspecified cardiac defect & & & $1^{\mathrm{a}}$ & \\
\hline Liver malformation + undescended testicle & & 1 & & \\
\hline Hypospadias & & 2 & & \\
\hline Hypospadias + VSD & & 1 & & \\
\hline Hypospadias + VSD + pulmonary atresia & & & & 1 \\
\hline Hypospadias + unspecified cardiac defect & & 1 & & \\
\hline Hypospadias + pes equinovarus + pulmonary artery stenosis & & 1 & & \\
\hline Renal dysplasia + ureter stenosis + PDA & & 1 & & \\
\hline Kidney malformation + vesico-ureteral reflux + PDA & & 1 & & \\
\hline Cystic kidney & & 3 & & \\
\hline Cystic kidney + VSD + nasal malformation & & & 1 & \\
\hline Hydronephrosis & & 2 & & $1^{\mathrm{a}}$ \\
\hline Ureter stenosis with hydronephrosis & & & $1^{\mathrm{a}}$ & \\
\hline Craniostenosis + ASD + pes equinovarus & & 1 & & \\
\hline Pes equinovarus & & 1 & & \\
\hline Polydactyly & & 1 & & \\
\hline Polydactyly + undescended testicle & & 1 & & \\
\hline Syndactyly & & 1 & & \\
\hline Unspecified syndrome with cleft palate & & & $1^{\mathrm{a}}$ & \\
\hline Marfan syndrome & & 1 & & \\
\hline Down syndrome & & 2 & & \\
\hline Trisomy 13 & & 1 & & \\
\hline \multicolumn{5}{|l|}{ Mild and variably registered malformations } \\
\hline Preauricular tag & & 2 & & \\
\hline Misshapen ear & & 1 & & \\
\hline Patent ductus arteriosus & & 1 & & \\
\hline
\end{tabular}


Table 9 (continued)

\begin{tabular}{|c|c|c|c|c|}
\hline Congenital malformation & $\begin{array}{l}\text { Sympaticus } \\
\text { blocker }\end{array}$ & $\begin{array}{l}\text { Beta-blocking } \\
\text { agent }\end{array}$ & $\begin{array}{l}\text { Calcium-channel } \\
\text { blocker }\end{array}$ & $\begin{array}{l}\mathrm{ACE} \\
\text { inhibitor }\end{array}$ \\
\hline Single umbilical artery & & 1 & & \\
\hline Hiatus hernia & & & & $1^{\mathrm{a}}$ \\
\hline Undescended testicle & & 4 & 1 & \\
\hline Undescended testicle + PDA & & 1 & & \\
\hline Undescended testicle + nevus & & & $1^{\mathrm{a}}$ & \\
\hline Unstable hip & $2^{\mathrm{a}}$ & 3 & & $1^{\mathrm{a}}$ \\
\hline Sterno-mastoid muscle anomaly & & 1 & & \\
\hline
\end{tabular}

ASD Atrium septum defect, HLHS hypoplastic left heart syndrome, PDA patent ductus arteriosus, VSD ventricular septum defect

${ }^{\mathrm{a}}$ The woman also used a beta-receptor blocking agent

In baboons, fetal death and intrauterine growth restriction were seen under treatment with ACE inhibitors, and it was hypothesized that the observed fetopathy could be due to a direct effect of the drug on the renin-angiotensin system in the primate fetus and is not merely an effect secondary to maternal hypotension [17]. Post-mortem examination of the baboon fetuses found no malformations.

In humans, hypocalvaria has been described in some cases [18-19]. Since membranous bones are highly vasculated and in need of high vascular oxygen tension during development, it has been postulated that fetal hypotension produced by ACE inhibitors could induce hypoxia thus resulting in hypocalvaria [18]. The renal development has also been described to be affected by fetal kidney hypotension, causing renal tubular dilatation or distal tubular hypoplasia [18-19]. These effects are suggested to occur, not in the first, but in the second and third trimesters [15].

In the previous study [8], an association between ACE inhibitors and CNS malformations was suggested, based on three cases, one with spina bifida, one with microcephaly (and an eye malformation), and one with coloboma-a condition usually not referred to as a CNS malformation. We found 5 infants with a CNS malformation compared with 2.2 expected, but none of the mothers had used an ACE inhibitor. No infant had a coloboma.

Table 10 Data on 19 infants who died after maternal use of antihypertensive drugs in early pregnancy

\begin{tabular}{llll}
\hline Age at death & Year & $\begin{array}{l}\text { Antihypertensives in } \\
\text { early pregnancy }\end{array}$ & $\begin{array}{l}\text { Antihypertensives } \\
\text { later in pregnancy }\end{array}$ \\
\hline Stillborn & 1998 & Lisinopil & Lisinopil \\
Stillborn & 2001 & Losartan & Unknown \\
Stillborn & 2001 & Atenolol + labetalol & Unknown \\
Stillborn & 2002 & Hydralazin & Atenolol \\
Stillborn & 2002 & Pindolol & Pindolol + isadipin \\
Stillborn & 2003 & Labetalol & Labetalol + hydralazin \\
Stillborn & 2004 & Metoprolol + losartan & Metoprolol \\
Stillborn & 2005 & Atenolol & Atenolol + labetalol \\
Stillborn & 2005 & Labetalol & Labetalol \\
Stillborn & 2005 & Labetalol & Labetalol \\
Stillborn & 2005 & Labetalol & Labetalol \\
Stillborn & 2006 & Labetalol & Labetalol \\
Stillborn & 2006 & Labetalol + felodipine + enalapril & Labetalol \\
Stillborn & 2006 & Unspecified beta-blocking agent & Labetalol \\
1 day & 1999 & Enalapril & Isradipin + atenolol \\
4 days & 1998 & Atenolol & Unknown \\
11 days & 1999 & Metoprolol & None \\
11 days & 2001 & Labetalol & Labetalol + isradipin \\
95 days & 1996 & Verapamil & Unknown \\
\hline
\end{tabular}

HLHS Hypoplastic left heart syndrome, SIDS sudden infant death syndrome

${ }^{a}$ Cause of death only for liveborns 
This study was large but also had limitations. Information on use of antihypertensives in early pregnancy was probably reasonably complete; if it was missing, it would transfer some truly exposed cases to the control group, which would hardly affect risk estimates. Little information was available on exact dosage and timing, but antihypertensive treatment is usually a long-term procedure. There was little information on the severity of the hypertension, either before treatment began or during early pregnancy. Hopefully, most treated women had achieved a good regulation of their blood pressure, but data were not available. Women with untreated hypertension in the beginning of pregnancy were not included and are difficult to identify as no information was available on blood pressure level at the first antenatal care visit. Ascertainment of congenital malformations was made from multiple sources. It may be incomplete but is most probably unbiased.

In conclusion, our data favor the interpretation that an association between maternal use of antihypertensives in early pregnancy and infant cardiovascular defects is not specific to ACE inhibitors but is also found after the use of other antihypertensives, notably beta-blocking agents. Further large studies on the relationship among maternal chronic hypertension, use of antihypertensive drugs, and congenital heart defects should be performed.

\section{References}

1. Rey E, Couturier A (1994) The prognosis of pregnancy in women with chronic hypertension. Am J Obst Gynecol 181:410-416

2. McCowan LM, Buist RG, North RA et al (1996) Perinatal morbidity in chronic hypertension. Br J Obstet Gynecol 103:123129

3. Sibal BM, Caritis SN, Hauth JC et al (2000) Preterm delivery in women with pregestational diabetes or chronic hypertension relative to women with uncomplicated pregnancies. The National Institute of Child Health and Human Development - Fetal Medicine Units Network. Am J Obst Gynecol 183:1520-1524
4. Ray JG, Burrows RF, Burrows E et al (2001) McMaster outcome study of hypertension in pregnancy. Early Hum Dev 64:129-143

5. Abalos E, Duley L, Steyn DW et al (2007) Antihypertensive drug therapy for mild to moderate hypertension during pregnancy. Cochrane Database of Systematic Reviews 1: CD002252. doi:10.1002/14651858.CD002252.pub2.

6. Heinonen OP, Slone D, Shapiro S (1977) Birth defects and drugs in pregnancy. Publishing Sciences Group, Littleton, MA

7. Källén B, Otterblad Olausson P (2003) Maternal drug use in early pregnancy and infant cardiovascular defect. Reprod Toxicol $17: 255-261$

8. Cooper WO, Hernandez-Diaz S, Arbogast P et al (2006) Major congenital malformations after first-trimester exposure to ACE inhibitors. New Engl J Med 354:2443-2451

9. National Board of Health and Welfare, Centre for Epidemiology (2003) The Swedish Medical Birth Register - a summary of content and quality. http://www.sos.se/FULLTEXT/112/2003-1123/2003-112-3.pdf. Accessed May 12, 2008

10. Källén B (1995) A birth weight for gestational age standard based on data in the Swedish Medical Birth Registry 1985-1989. Eur J Epidemiol 11:601-606

11. National Board of Health and Welfare, Centre for Epidemiology (2004) Registration of congenital malformations in Swedish health registers. http:/www.socialstyrelsen.se/Publicerat/2004/5120/ 2004-112-1.htm. Accessed May 12, 2008

12. Källén B, Otterblad Olausson P (2001) Monitoring of maternal drug use and infant congenital malformations. Does loratadine cause hypospadias? Int J Risk Safety Med 14:115-119

13. Åberg A, Westbom L, Källén B (2001) Congenital malformations among infants whose mothers had gestational or preexisting diabetes. Early Hum Develop 61:85-95

14. Scialli AR, Lione A (2006) ACE inhibitors and major congenital malformations (letter). New Engl J Med 355:1280

15. Briggs GG, Freeman RK, Yaffe SJ (2005) Drugs in pregnancy and lactation, 7th edn. Lippincott Williams and Wilkins, Philadelphia

16. Barr M Jr (1994) Teratogen update: angiotensin-converting enzyme inhibitors. Teratology 50:399-409

17. Harewood WJ, Phippard AF, Duggin G et al (1994) Fetotoxicity of angiotensin-converting enzyme inhibition in primate pregnancy: a prospective, placebo-controlled study in baboons (Papio hamadryas). Am J Obstet Gynecol 171:633-642

18. Buttar HS (1997) An overview of the influence of ACE inhibitors on fetal-placental circulation and perinatal development. Mol Cell Biochem 176:61-71

19. Tabacova S (2005) Mode of action: angiotensin-converting enzyme inhibition-developmental effects associated with exposure to ACE inhibitors. Crit Rev Toxicol 35:747-755 